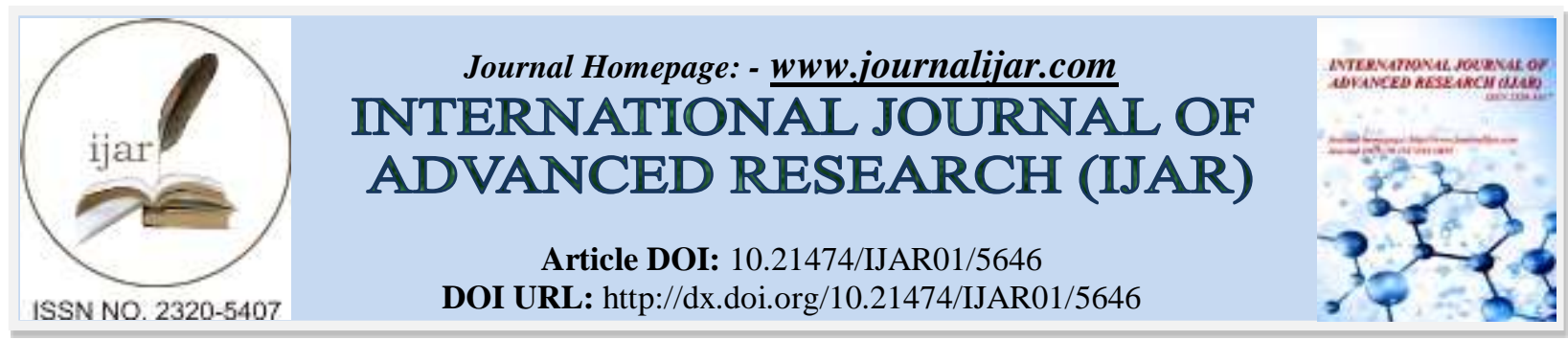

RESEARCH ARTICLE

\title{
A STUDY ON THE IMPACT OF AGRICULTURAL PRODUCT IMPORT \& EXPORT ON TOTAL AGRICULTURAL OUTPUT IN CHINA.
}

Yugang He.

Ph.D., Department of International Trade, Graduate School, Chonbuk National University, South Korea.

\section{Manuscript Info}

Manuscript History

Received: 17 August 2017

Final Accepted: 19 September 2017

Published: October 2017

Key words:-

Agricultural Product Import \& Export,

Agricultural Product Export,

Agricultural Product Import, Total

Agricultural Output, Production

Function of Export Extension.

JEL Classifications: B41, C22, F1, N5

\begin{abstract}
China remains a predominantly rural society, with only small percent living in urban areas. The purpose of this paper is to explore the impact of agricultural product import \& export on total agricultural output in China. In order to make the impact of agricultural product import \& export on total agricultural output be more clear, this paper applies data-sets from 1990-2016 to perform an empirical analysis based on the production function of export extension. The results show $1 \%$ increase in the agricultural product export will result in $0.532 \%$ in the total agricultural output. $1 \%$ increase in the agricultural product import will result in $0.470 \%$ in the total agricultural output. $1 \%$ increase in the agricultural product export will result in $0.510 \%$ in the total agricultural output. It can be concluded that the agricultural product import \& export makes great contribution to the total agricultural output. Furthermore, the contribution of agricultural product export on total agricultural output is greater than that of agricultural product import. This suggests that China's government should open its agricultural market more to the world so as to promote the growth of total agricultural output.
\end{abstract}

Copy Right, IJAR, 2017,. All rights reserved.

\section{Introduction:-}

With the economic globalization, most countries' mainstay industry have be transformed to the manufacturing industry or tertiary industry, especially in the industrial countries. However, large number of developing and underdeveloped countries' pillar industry is still the agriculture industry. China is not only the largest developing country but also its economic aggregate also reaches the second in the world. Because of this, quantities of economic scholars and experts spare no effort to find out the reason why China can realize these achievements. Therefore, this paper set China as an example for the periods of 1990 to 2016 to explore the impact of agricultural product import \& export on total agricultural output.

Agriculture industry encircles a variety of procedures wherein natural resources give rise to a number of products. Agriculture Industry consists of different activities which include harvesting crops, plants, livestock feeding, grazing etc. Agriculture industry encompasses preparing the soil for optimum returns, improving crops, services relating to horticulture, landscaping services, veterinary services, managing labors or farmers etc. Agriculture industry is always seeking to improve by adopting new technologies. The new technologies aim at improving the efficiency of various agricultural based operations. 
China is also a biggest developing country in exporting and importing the agricultural product. In 2016, the export amount of agricultural product is up to 72.61 billion dollars. Meanwhile, the import amount of agricultural product is also up to 110.61 billion dollars. Compared with two values above, at present, it is obvious that China is still a big agricultural product import country. Of Course, China's agricultural product exports to every corner in the world just as figure 1 shows.

Figure 1:- Export amount in the whole year of 2016.

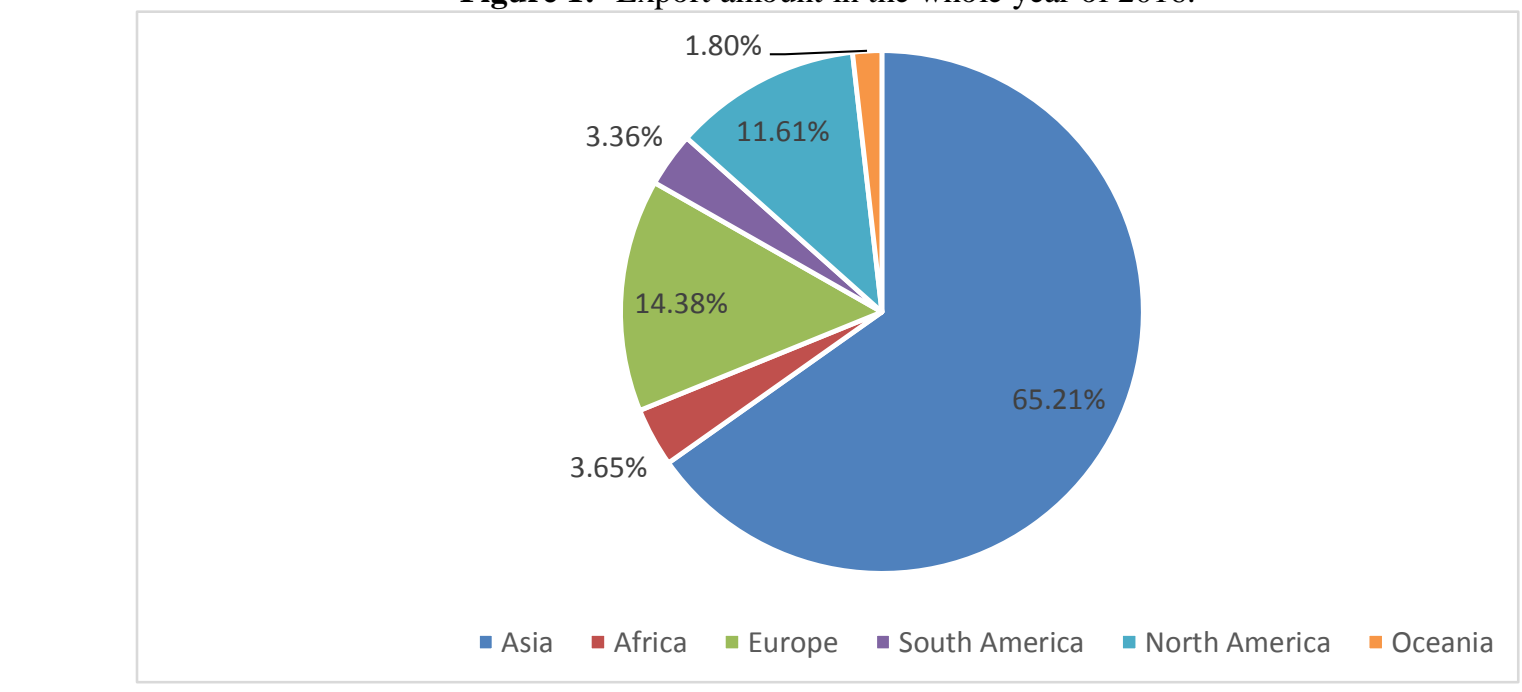

Unit: million dollar; Source: Ministry of Commerce of the People's Republic of China

Figure 1 shows the specific condition of agricultural products in the whole year of 2016 in China. 65.21\% agricultural product exports to Asia; 3.65\% agricultural product exports to Africa; $14.38 \%$ agricultural product exports to Europe; $3.36 \%$ agricultural product exports to South America; $11.61 \%$ agricultural product exports to North America and $1.80 \%$ agricultural product exports to Oceania.

The purpose of this paper is to explore the impact of agricultural product import \& export on total agricultural output in China. In order to make the impact of agricultural product import \& export on total agricultural output more clear, this paper applies data-sets from 1990-2016 to perform an empirical analysis based on the production function of export extension. The rest of this paper is structured as follow: Section 2 will have review on literature. Section 3 will provide the theoretical framework and methodology. Section 4 will present the result and interpretation. Section 5 will be the conclusion from this study.

\section{Literature Review:-}

The aim of this study is to examine the impact of agricultural product import \& export on total agricultural output in China for the periods of 1990 to 2016. There are some studies done in the past controversial on the empirical findings on this topic still exist.

Greyling (2012) finds that the agricultural sector has been unable to meet the demand for the main food items consumed domestically since 2000. This, however, does not result in the predicted rapid increase in food and general inflation. Agricultural exports have not played a growth-leading, but rather a balancing role in economic development, because the sector maintains a positive trade balance during the full period of analysis. The sector has released labour to the rest of the economy since 1962, thereby fulfilling what is seen as a requirement by the economic development literature. The sector has probably made a net transfer of capital to the rest of the economy since the mid-2000s. The agricultural sector plus the sectors with which it has the strongest linkages represented around $7 \%$ of the economy in 2010 .

De Silva, Malaga and Johnson (2013) examine the effects of trade liberalization on agricultural sector. Their paper provides a quantitative assessment of the trade policy impacts on agricultural sector growth in Sri Lanka based on the national data from 1960 to 2010. The Ordinary Least Square method and the multiple regression models are employed to investigate whether the trade policy reforms increase the agricultural sector growth or not. The 
empirical results suggest that the trade liberalization on agricultural sector growth and eventually lead to improved agricultural proclivity. Moreover, this analysis concludes that the trade openness, investment, interest rate and free trade agreements are significant factors that are positively related to agricultural sector growth. This research also confirms that the agricultural sector growth has made a wide contribution to total GDP to accelerate the economic growth in post-liberalization period in Sri Lanka. In the past three decades, global agriculture losses have continuously grown due to increasingly severe droughts. Compared with direct economic effects, there are great difficulties in evaluating the indirect economic effects of drought, which has severely lagged behind the urgent information needs for decision making. Lin, Deng and Jin (2013) try to solve the perplexity in the evaluation of the effects of drought on the price fluctuation of agricultural products by building a partial equilibrium model that describes the balancing process of supply and demand quantitatively. Using this model, a scenario analysis is applied to evaluate the price fluctuation of agricultural products caused by drought in North China. The results indicate that there is no major impact of drought on the market prices of eight major agricultural products. Even with the occurrence of a severe drought in North China, market prices of agricultural products will rise no more than 3.59 percent, which is less than the normal market price fluctuations of China's agricultural products. Their study provides a tool for evaluating indirect economic effects of drought. The results of our case study could support decision making for China's food market regulation. Olayiwola and Ola-David (2013) examine the interaction between economic integration and trade facilitation in ECOWAS and how the regional bloc has performed in promoting agricultural export. Statistical and econometric analyses are utilized to examine the effect of economic integration on trade facilitation as well as the role of trade facilitation and economic integration in promoting agricultural exports in ECOWAS. Their findings suggest that on the average, the level of trade facilitation in ECOWAS is below world average. It is also found that ECOWAS members with more bureaucratic processes experience greater costs of exporting or importing. Evidence from the study also reveals a sustained growth in agricultural production and a close relationship between agricultural production and agricultural exports in the region. Results from econometric analyses indicate that economic integration significantly helps in facilitating trade within the ECOWAS sub-region. Economic integration and trade facilitation were also found to be significant in influencing agricultural exports in the ECOWAS sub-region, while agricultural production had direct and significant impact on agricultural exports. Notably, there is a need to create incentives for greater level of implementation of the ECOWAS agricultural policy (ECOWAP) and the ECOWAS Trade liberalization Scheme (ETLS) protocols by individual member states to enhance economic integration in the sub-region. Klobuchar (2013) find that the agricultural sector makes an important contribution to the U.S. economy, from promoting food and energy security to supporting jobs in communities across the country. Exports are critical to the success of U.S. agriculture, and population and income growth in developing countries ensures that this will continue to be the case in the decades to come. U.S. agricultural exporters are well-positioned to capture a significant share of the growing world market for agricultural products, but some challenges remain. Taking actions to facilitate exports would help to strengthen the agricultural sector and promote overall economic growth.

Syed Waseem Gilani (2015) analyzes the impact of agricultural exports and imports on agricultural productivity secondly to it also analyzes the effect of exports on imports or moreover it analyzes the causal relationship agriculture exports, agricultural imports and agricultural productivity. Variable which they have taken to fulfill our objective are agricultural productivity, agricultural imports, agricultural exports whereas agricultural productivity is dependent variable and agricultural imports, agricultural exports are independent variable data which we had taken is from 1980 to 2010. So for this they have done certain methodology in which they have done pair wise Granger causality and so by analyzing results they have seen the causality between these variable. By the results they have concluded that agricultural exports and agricultural productivity has a bi-directional causality and imports and exports have unidirectional causality whereas agricultural imports in terms of finished products and agricultural productivity have no causality because when the income of the peoples increases so this leads to increase in the imports this do not affect the agricultural productivity. Yao and Wan (2015) is based on the studies of Andersen and Van Wincoop (2003) and Abulaiti Yiming (2013) to construct unilateral trade model to analyze the trend of China's agricultural export cost to the United States and its impact on export growth. The results show that: After joining the WTO, the trend of China's agricultural export cost to the United States is the first dropping then rising. Although the overall magnitude of change is slow, its contribution rate is great to China's agricultural export growth to the United States.

Uremadu and Onyele (2016) analyze the impact of selected agricultural exports on economic growth in Nigeria from 1980 to 2014. It specifically examines the determinants of total agricultural export supply, cocoa export supply and rubber export supply; their export performance and determining factors. Both export crops were chosen because 
they remain the most exported agricultural commodities from Nigeria, and published national aggregates on specific trade and macroeconomic variables in CBN Statistical Bulletin (various years) and National Bureau of Statistics (NBS). For the data analysis, descriptive statistic and ordinary least square (OLS) were used. The results revealed that export supply of cocoa was insignificant, but had a positive impact on real GDP, while the coefficient of export supply of rubber was negative and insignificant at 5\% level. Export commodity price index was found to be significant with a positive impact on real GDP, depicting that export commodity prices have been favourable during the period under study. Domestic economic growth (proxied by real GDP) was influenced positively by exchange rate, interest rate, and trade openness, but only exchange rate was significant, while inflation rate had a negative impact on economic growth. The results further showed that the aggregate agricultural exports was positive and had a significant impact on economic growth in Nigeria. The study therefore recommended policy options such as export financing, value addition to cocoa beans being exported, and favourable foreign exchange policies to promote production in the export subsector of agriculture and industrial sector for proper diversification of Nigerian economy in the years ahead. Towards the acceleration of the attainment of sustainable growth, most countries have focused on agricultural exports as a means of driving their economy. Developing countries of Africa are highly dependent on the agricultural sector and agricultural exports are a major determinant of economic growth of these countries. However, the impact of agricultural exports on economic growth of ECOWAS countries remains unclear. Edeme, Ifelunini and Nkalu (2016) evaluate the impact of agricultural exports on the economic growth of fifteen ECOWAS countries using panel data for the period 1980-2013. Variables employed are labour force participation rate, capital stock, agricultural exports, non-agricultural exports, inflation and economic growth. The results of the fixed-effect model show that agricultural exports have not impacted significantly on the economic growth of ECOWAS countries such as Côte d'Ivoire and Nigeria with respect to the Republic of Benin, which is the selected baseline. The study also analysed the country combined effect of the agricultural exports and found that it was significant but the rate of impact was weak. The study recommends, among others, that even though agricultural exports had a significant impact on economic growth, there is still a need for ECOWAS governments to improve their agricultural sector as its significance is more noticeable in some countries such as Côte d' Ivoire and Nigeria. Godoy and Dewbre (2016) seek to distil lessons from Vietnam "es outstanding agricultural progress for policy makers wishing to foster agricultural performance for poverty reduction in other developing countries. We begin with a brief overview of macroeconomic and trade policy developments and selected indicators of economic performance. We then turn to a slightly more in-depth discussion of the profound changes to Vietnam "s agricultural policy and the turnaround in sectoral performance they engendered. The following section chronicles the evolution of income distribution and poverty, exploiting the data obtained from poverty surveys implemented first in 1993 and then in two-year intervals beginning in 1998 through 2008. The fourth and last substantive section discusses findings from analysis aimed at quantifying agriculture"s contribution to poverty reduction achieved in Vietnam. The final section concludes and draws some policy implications. Nesme, Roques, Metson and Bennett (2016) also find the same results. 孙 and 张 (2016) use the vector autoregression model to analyze the relationship between agricultural product import \& export. Via empirical analysis, they find that there is long-run equilibrium relationship among agricultural product import, agricultural product export and agricultural structure. The agricultural structure has a negative effect on agricultural product import \& export. However, After adjustment, its effect on agricultural product import \& export become positive. 孙, 胡 and刘 (2016) also achieve the same findings.

Chang (2017) finds that since ancient times, China is a country with a large population and abundant agriculture. With the reform of China's market economy and entered WTO, it has improved the international participation degree of agricultural products in China. Especially in recent years, in the highly open international markets and countries have pledged to weaken their agricultural support, China's agricultural products in the international market ushered in a broader space for development, but due to various reasons, China's agricultural products trade has formed a huge deficit in recent years. To reduce the trade deficit, continue to expand exports of agricultural products, create income for China's foreign exchange and increase farmers' income, we need to continue improving the international competitiveness of China's agricultural products. 钟 (2017) analyzes the operating mechanism between international trade of agricultural product and economic growth in China. He points out that the advancement and improvement of structure of agricultural product import \& export can promote the economic growth in China.

\section{Model:-}

In economics, more precisely econometrics, the Cobb-Douglas production function is a particular functional form of the production function, widely used to represent the technological relationship between the amounts of two or more 
inputs, particularly physical capital and labor, and the amount of output that can be produced by those inputs. The Cobb-Douglas form was developed and tested against statistical evidence by Charles Cobb and Paul Douglas.

This paper is based on the production function of export extension which is derived from from the Cobb-Douglas production function to analyze the impact of agricultural product import \& export on total agricultural output in China. Furthermore, this also uses the Balassa's production function of export extension (Balassa (1978) extended the traditional production function into production function of export extension which can be used in the open economy) for reference. In Balassa's production function of export extension, the reason why the export volume can be regarded as the independent variable such as the capital factor and the labor factor to promote the output is that the export can expend the economic effect of scale of production and it also can promote technological progress so as to increase the efficiency of production factors. Thus, this provides some rationality for the export volume which can be treated as the independent variable to explain the total output. However, the export volume, capital factor and labor factor exist the correlation when they are treated as the independent variable under a certain conditions. Because of this, the multicollinearity can be produced. So, the explanatory ability of the whole function will be affected. The derivative process of Balassa's production function of export extension gives in specific below.

The Cobb-Douglas function form can be estimated as a linear relationship using the following expression.

$$
\ln (Y)=a_{0}+\sum_{i=1}^{n} a_{i} \ln \left(I_{i}\right)
$$

Where $Y$ is the output; $I_{i}$ is the inputs; $a_{i}$ is the model coefficients; $i=1,2,3 \ldots n$.

Rewriting equation (1) gives:

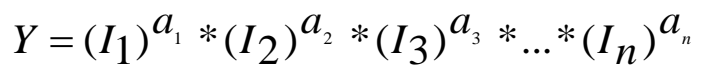

The Balassa's production function of export extension gives:

$$
Y=K^{\alpha}{ }^{\beta}{ }_{I} \gamma_{E} \varepsilon
$$

Where $Y$ is the total output; $K$ is the capital input; $L$ is the labor input; $I$ is the growth rate of export volume;

$\alpha, \beta, \gamma, \varepsilon$ are the output elasticity; $E^{\mathcal{E}}$ is the white noise.

Taking the logarithm on the both sides of equation (3) gives:

$$
\ln Y=a_{0}+\alpha \ln K+\beta \ln L+\gamma \ln I+\varepsilon
$$

Equation (4) is called the Balassa's production function of export extension. It has been widely used in the international economic field to evaluate the impact of international trade on economic growth. This paper is based on the previous researches about this topic to explore the impact of agricultural product import \& export on total agricultural output in China.

The model of this paper gives:

$$
\ln Y^{A}=a_{0}^{A}+\alpha \ln K^{A}+\beta \ln L^{A}+\gamma \ln I^{A}+\varepsilon^{A}
$$

Where $Y^{A}$ is the agricultural total output; $a_{0}^{A}$ is the constant; $K^{A}$ is the agricultural capital input; $L^{A}$ is the agricultural labor input; $I^{A}$ are the agricultural product import \& export, agricultural export and agricultural import which will be put into the model one by one to analyze the their impacts on agricultural total output; $\alpha, \beta, \gamma$ are the output elasticity of then; $\varepsilon^{A}$ is the white noise.

\section{Empirical Analysis:- Data descriptive:}

This paper applies data-sets from 1990 to 2016 to explore the impact of agricultural product import \& export, product export and product import on total agricultural output in China. All data-sets are sourced from the National Bureau of statistics of the People' s Republic of China. all data-sets are deflated by consumer price index. In order to get rid of the heteroscedasticity, all variables are taken the logarithm. They will be shown in table 1 . 
Table 1:- Variables

\begin{tabular}{|l|l|l|}
\hline Variable & Logarithmic form & Source \\
\hline Total agricultural output & $\ln T A O$ & $\begin{array}{l}\text { National Bureau of statistics of the People' s } \\
\text { Republic of China }\end{array}$ \\
\hline Agricultural capital input & $\ln A C I$ & $\begin{array}{l}\text { National Bureau of statistics of the People' s } \\
\text { Republic of China }\end{array}$ \\
\hline Agricultural product import \& export & $\ln A L I$ & $\begin{array}{l}\text { National Bureau of statistics of the People' s } \\
\text { Republic of China }\end{array}$ \\
\hline Agricultural product import & $\begin{array}{l}\text { National Bureau of statistics of the People' s } \\
\text { Republic of China }\end{array}$ \\
\hline Agricultural product export & $\begin{array}{l}\text { National Bureau of statistics of the People' s } \\
\text { Republic of China }\end{array}$ \\
\hline
\end{tabular}

\section{Correlation test:-}

If the complicated correlation between the explanatory variable and the explained variable exists, the multiple mutual linear problem will be generated when conducting the multiple regression analysis. Due to this, it is hard to confirm the relationship between the explanatory variable and the explained variable. Therefore, it is necessary to test the correlation between the explanatory variable and the explained variable. The results show in table 2 .

Table 2:- Correlation test of all variables

\begin{tabular}{|l|l|l|l|l|l|l|}
\hline & $\ln T A O$ & $\ln A C I$ & $\ln A L I$ & $\ln A P I E$ & $\ln A P I$ & $\ln A P E$ \\
\hline $\ln T A O$ & 1.000 & 0.997 & 0.980 & 0.986 & 0.984 & 0.987 \\
\hline $\ln A C I$ & 0.997 & 1.000 & 0.968 & 0.981 & 0.979 & 0.981 \\
\hline $\ln A L I$ & 0.980 & 0.968 & 1.000 & 0.988 & 0.987 & 0.988 \\
\hline $\ln A P I E$ & 0.986 & 0.981 & 0.988 & 1.000 & 0.999 & $1.000^{*}$ \\
\hline $\ln A P I$ & 0.984 & 0.979 & 0.987 & 0.999 & 1.000 & 0.998 \\
\hline $\ln A P E$ & 0.987 & 0.981 & 0.988 & $1.000^{*}$ & 0.998 & 1.000 \\
\hline
\end{tabular}

$1.000 *$ is a value by rounding

Table 2 suggests that the the total agricultural output, agricultural capital input, agricultural labor input, agricultural product import \& export, agricultural product import and agricultural product export exist positive correlation in statistics from 1990 to 2016. Namely, it indicates that the positive mutual promoted-effect among variables exists. Specifically, table 2 shows that each variable mentioned has a significant correlation with the total agricultural output in China.

\section{Unit root test:-}

In order to avoid the spurious regression, all data-sets should be test their stationarity. The Augmented DickeyFuller test will be used in this paper. The testing model gives:

$$
\Delta y_{t}=\alpha+\beta t+\gamma y_{t-1}+\delta \Delta y_{t-1}+\ldots+\delta_{p-1} \Delta y_{t-p+1}+\varepsilon_{t}
$$

Where where $\alpha$ is a constant; $\beta$ the coefficient on a time trend and $p$ the lag order of the auto regressive process; $\varepsilon_{t}$ is the white noise. The unit root test is then carried out under the null hypothesis $\gamma=0$ against the alternative hypothesis of $\gamma=0$.

$$
D F_{\tau}=\frac{\breve{\gamma}}{S E(\breve{\gamma})}
$$

Once a value for the test statistic is computed it can be compared to the relevant critical value for the Dickey-Fuller Test. If the test statistic is less (this test is non symmetrical so we do not consider an absolute value) than the (larger 
negative) critical value, then the null hypothesis of $\gamma=0$ is rejected and no unit root is present. The results of unit root test show in table 3 .

Table 3:- Unit root test

\begin{tabular}{|l|l|l|l|}
\hline Variable & t-Statistic & $5 \%$ test critical value & Prob. $^{*}$ \\
\hline $\ln T A O$ & -1.859 & -2.992 & 0.345 \\
\hline$\Delta \ln T A O$ & -3.076 & -2.992 & 0.042 \\
\hline $\ln A C I$ & -2.067 & -2.981 & 0.259 \\
\hline$\Delta \ln A C I$ & -7.085 & -2.992 & 0.000 \\
\hline $\ln A L I$ & -0.744 & -2.986 & 0.817 \\
\hline$\Delta \ln A L I$ & -9.260 & -2.981 & 0.000 \\
\hline $\ln A P I E$ & -0.174 & -3.595 & 0.990 \\
\hline$\Delta \ln A P I E$ & -3.110 & -2.981 & 0.038 \\
\hline $\ln A P I$ & 1.333 & -1.955 & 0.950 \\
\hline$\Delta \ln A P I$ & -3.429 & -2.981 & 0.019 \\
\hline $\ln A P E$ & -2.630 & -2.981 & 0.100 \\
\hline$\Delta \ln A P E$ & -3.982 & -2.633 & 0.006 \\
\hline$\Delta \ln$ & & \\
\hline
\end{tabular}

$\Delta$ represents the first difference of all variables

Table 3 indicates that all variables are non stationary under 5\% significance level. However, after the first difference, all variables become stationary under 5\% significance level. In order to make the long-run relationship among variables more clear, it is necessary to conduct the cointegration test in the next step.

\section{Cointegration test:-}

The Johansen test is a test for cointegration that allows for more than one cointegrating relationship, unlike the Engle-Granger method, but this test is subject to asymptotic properties. This paper uses the Johansen cointegration test to explore the long-run relationship among these variables.

\section{Cointegration test $(\ln T A O, \ln A C I, \ln A L I$ and $\ln A P E$ )}

Table 4 and table 5 show the long-run relationship among the total agricultural output, agricultural capital input, agricultural labor input and agricultural product export.

Table 4:- Unrestricted Cointegration Rank Test (Trace)

\begin{tabular}{|l|l|l|l|l|}
\hline Hypothesized No. Of CE(s) & Eigenvalue & Trace Statistic & 0.05 Critical Value & Prob.** \\
\hline None* & 0.750 & 79.257 & 47.856 & 0.000 \\
\hline At most $1^{*}$ & 0.649 & 44.604 & 29.797 & 0.001 \\
\hline At most $2^{*}$ & 0.462 & 18.465 & 15.495 & 0.017 \\
\hline At most 3 & 0.111 & 2.945 & 3.841 & 0.086 \\
\hline
\end{tabular}

Trace test indicates 3 cointegrating eqn(s) at the 0.05 level. * denotes rejection of the hypothesis at the 0.05 level . **MacKinnon-Haug-Michelis (1999) p-values

Table 4 indicates that the trace test of them. The results show that there are at most 2 cointegrations among them under 5\% significant level.

Table 5:- Unrestricted Cointegration Rank Test (Maximum Eigenvalue)

\begin{tabular}{|l|l|l|l|l|}
\hline Hypothesized No. Of CE(s) & Eigenvalue & Max-Eigen Statistic & 0.05 Critical Value & Prob.** \\
\hline None* & 0.750 & 34.653 & 27.584 & 0.005 \\
\hline At most $1^{*}$ & 0.649 & 26.139 & 21.132 & 0.009 \\
\hline At most 2* & 0.462 & 15.520 & 14.265 & 0.032 \\
\hline At most 3 & 0.111 & 2.945 & 3.841 & 0.086 \\
\hline
\end{tabular}

Max-eigenvalue test indicates 3 cointegrating eqn(s) at the 0.05 level. $*$ denotes rejection of the hypothesis at the 0.05 level. **MacKinnon-Haug-Michelis (1999) p-values 
Table 4 indicates that the maximum eigenvalue test of them. The results also show that there are at most 2 cointegrations among them under 5\% significant level.

Cointegration test $(\ln T A O, \ln A C I, \ln A L I$ and $\ln A P I)$

Table 6 and table 7 show the long-run relationship among the total agricultural output, agricultural capital input, agricultural labor input and agricultural product import.

Table 6:- Unrestricted Cointegration Rank Test (Trace)

\begin{tabular}{|l|l|l|l|l|}
\hline Hypothesized No. Of CE(s) & Eigenvalue & Trace Statistic & 0.05 Critical Value & Prob.** \\
\hline None* & 0.804 & 97.054 & 47.856 & 0.000 \\
\hline At most $1^{*}$ & 0.722 & 56.344 & 29.797 & 0.000 \\
\hline At most 2* & 0.538 & 24.319 & 15.495 & 0.002 \\
\hline At most $3^{*}$ & 0.181 & 4.989 & 3.841 & 0.026 \\
\hline
\end{tabular}

Trace test indicates 4 cointegrating eqn(s) at the 0.05 level. * denotes rejection of the hypothesis at the 0.05 level . **MacKinnon-Haug-Michelis (1999) p-values

Table 6 indicates that the trace test of them. The results show that there are at most 3 cointegrations among them under 5\% significant level.

Table 7:- Unrestricted Cointegration Rank Test (Maximum Eigenvalue)

\begin{tabular}{|l|l|l|l|l|}
\hline Hypothesized No. Of CE(s) & Eigenvalue & Max-Eigen Statistic & 0.05 Critical Value & Prob.** \\
\hline None* & 0.804 & 40.710 & 27.584 & 0.001 \\
\hline At most * $^{*}$ & 0.722 & 32.025 & 21.132 & 0.001 \\
\hline At most 2* & 0.538 & 19.329 & 14.265 & 0.007 \\
\hline At most 3* & 0.181 & 4.989 & 3.841 & 0.026 \\
\hline
\end{tabular}

Max-eigenvalue test indicates 4 cointegrating eqn(s) at the 0.05 level. * denotes rejection of the hypothesis at the 0.05 level. **MacKinnon-Haug-Michelis (1999) p-values

Table 7 indicates that the maximum eigenvalue test of them. The results also show that there are at most 3 cointegrations among them under 5\% significant level.

\section{Cointegration test $(\ln T A O, \ln A C I, \ln A L I$ and $\ln A P I E)$}

Table 8 and table 9 show the long-run relationship among the total agricultural output, agricultural capital input, agricultural labor input and agricultural product import \& export.

Table 8:- Unrestricted Cointegration Rank Test (Trace)

\begin{tabular}{|l|l|l|l|l|}
\hline Hypothesized No. Of CE(s) & Eigenvalue & Trace Statistic & 0.05 Critical Value & Prob.** \\
\hline None* & 0.756 & 81.565 & 47.856 & 0.000 \\
\hline At most $1^{*}$ & 0.642 & 46.260 & 29.797 & 0.000 \\
\hline At most 2* & 0.489 & 20.601 & 15.495 & 0.008 \\
\hline At most 3 & 0.142 & 3.835 & 3.841 & 0.050 \\
\hline
\end{tabular}

Trace test indicates 3 cointegrating eqn(s) at the 0.05 level. $*$ denotes rejection of the hypothesis at the 0.05 level .**MacKinnon-Haug-Michelis (1999) p-values

Table 8 indicates that the trace test of them. The results show that there are at most 2 cointegrations among them under 5\% significant level.

Table 9:- Unrestricted Cointegration Rank Test (Maximum Eigenvalue)

\begin{tabular}{|l|l|l|l|l|}
\hline Hypothesized No. Of CE(s) & Eigenvalue & Max-Eigen Statistic & 0.05 Critical Value & Prob.** \\
\hline None* & 0.756 & 35.305 & 27.584 & 0.004 \\
\hline At most * $^{*}$ & 0.642 & 25.659 & 21.132 & 0.011 \\
\hline At most 2* & 0.489 & 16.767 & 14.265 & 0.020 \\
\hline At most 3 & 0.142 & 3.835 & 3.841 & 0.050 \\
\hline
\end{tabular}


Max-eigenvalue test indicates 3 cointegrating eqn(s) at the 0.05 level. * denotes rejection of the hypothesis at the 0.05 level. **MacKinnon-Haug-Michelis (1999) p-values

Table 9 indicates that the maximum eigenvalue test of them. The results also show that there are at most 2 cointegrations among them under $5 \%$ significant level.

\section{Regression equation:-}

Based on the production function of export extension mentioned in sector 2, this model is used to analyze the impact of the foreign trade of agricultural product on total agricultural output. More specifically, the empirical analysis will be divided into three parts: (1) the impact of agricultural product export on total agricultural output. (2) the impact of agricultural product import. (3) the impact of agricultural product import \& export.

\section{Regression equation $(\ln T A O, \ln A C I, \ln A L I$ and $\ln A P E)$}

Before performing the regression, $I$ is replaced by the agricultural product export. Additionally, in order to remove the correlation among variables, $A R(1)$ is put into the regression equation of the impact of agricultural product export on total agricultural output.

Table 10:- Regression equation result (1)

\begin{tabular}{|l|l|l|l|l|}
\hline Variable & Coefficient & Std. Error & t-Statistic & Prob. \\
\hline $\ln A C I$ & 0.364 & 0.102 & 3.573 & 0.002 \\
\hline $\ln A L I$ & 0.476 & 0.157 & 3.030 & 0.006 \\
\hline $\ln A P E$ & 0.532 & 0.265 & 2.004 & 0.048 \\
\hline$A R(1)$ & 0.972 & 0.024 & 39.789 & 0.000 \\
\hline & $R^{2}=0.9988$ & & Adjusted $^{2}=0.9986$ & \\
\hline
\end{tabular}

The estimated regression equation gives:

$$
\ln T A O=0.364 \ln A C I+0.476 \ln A L I+0.532 \ln A P E+0.972 A R(1)+\varepsilon
$$

Table 10 indicates the result of regression analysis. The degree of fitting of empirical model is up to $99.88 \%$. Also and the adjusted value is also up to $99.86 \%$. All variables get through 5\% significant level, so does $A R(1)$. Furthermore, all coefficients of explained variables are positive. Namely, they have a positive relation with the total agricultural output. This point is also in accordance with the theoretical analysis. Equation (8) suggests that all variables have a positive promoted-effect on total agricultural output. More specifically, $1 \%$ increase in the agricultural capital input will result in $0.364 \%$ in the total agricultural output. $1 \%$ increase in the agricultural labor input will result in $0.476 \%$ in the total agricultural output. $1 \%$ increase in the agricultural product export will result in $0.532 \%$ in the total agricultural output. Compared with the cointegration test, the result demonstrates that the agricultural product export has a long-run positive promoted-effect on total agricultural output.

\section{Regression equation $(\ln T A O, \ln A C I, \ln A L I$ and $\ln A P I)$}

Before performing the regression, $I$ is replaced by the agricultural product import. In order to remove the correlation among variables, $A R(1)$ is put into the regression equation of the impact of agricultural product import on total agricultural output.

Table 11:- Regression equation result (2)

\begin{tabular}{|l|l|l|l|l|}
\hline Variable & Coefficient & Std. Error & t-Statistic & Prob. \\
\hline $\ln A C I$ & 0.329 & 0.108 & 3.036 & 0.006 \\
\hline $\ln A L I$ & 0.197 & 0.054 & 3.629 & 0.002 \\
\hline $\ln A P I$ & 0.470 & 0.825 & 0.570 & 0.045 \\
\hline$A R(1)$ & 0.969 & 0.019 & 49.792 & 0.000 \\
\hline
\end{tabular}




\begin{tabular}{|l|l|l|l|l|}
\hline & $R^{2}=0.9985$ & & Adjusted $^{2}=0.9983$ & \\
\hline
\end{tabular}

The estimated regression equation gives:

$$
\ln T A O=0.329 \ln A C I+0.197 \ln A L I+0.470 \ln A P I+0.969 A R(1)+\varepsilon
$$

Table 11 indicates the result of regression analysis. The degree of fitting of empirical model is up to $99.85 \%$. Also and the adjusted value is also up to $99.83 \%$. All variables get through 5\% significant level, so does $A R(1)$. Furthermore, all coefficients of explained variables are positive. Namely, they have a positive relation with the total agricultural output. This point is also in accordance with the theoretical analysis. Equation (9) suggests that all variables have a positive promoted-effect on total agricultural output. More specifically, $1 \%$ increase in the agricultural capital input will result in $0.329 \%$ in the total agricultural output. $1 \%$ increase in the agricultural labor input will result in $0.197 \%$ in the total agricultural output. $1 \%$ increase in the agricultural product import will result in $0.470 \%$ in the total agricultural output. Compared with the cointegration test, the result demonstrates that the agricultural product import has a long-run positive promoted-effect on total agricultural output.

\section{Regression equation $(\ln T A O, \ln A C I, \ln A L I$ and $\ln A P I E$ )}

Before performing the regression, $I$ is replaced by the agricultural product import \& export. In order to remove the correlation among variables, $A R(1)$ is put into the regression equation of the impact of agricultural product import $\&$ export on total agricultural output.

Table 12:- Regression equation result (3)

\begin{tabular}{|l|l|l|l|l|}
\hline Variable & Coefficient & Std. Error & t-Statistic & Prob. \\
\hline $\ln A C I$ & 0.305 & 0.120 & 2.551 & 0.019 \\
\hline $\ln A L I$ & 0.397 & 0.096 & 4.307 & 0.000 \\
\hline $\ln A P I E$ & 0.510 & 0.214 & 2.380 & 0.014 \\
\hline$A R(1)$ & 0.962 & 0.017 & 57.600 & 0.000 \\
\hline & $R^{2}=0.9983$ & & AdjustedR $^{2}=0.9981$ & \\
\hline
\end{tabular}

The estimated regression equation gives:

$$
\ln T A O=0.305 \ln A C I+0.397 \ln A L I+0.510 \ln A P I+0.962 A R(1)+\varepsilon
$$

Table 10 indicates the result of regression analysis. The degree of fitting of empirical model is up to $99.88 \%$. Also and the adjusted value is also up to $99.86 \%$. All variables get through $5 \%$ significant level, so does $A R(1)$. Furthermore, all coefficients of explained variables are positive. Namely, they have a positive relation with the total agricultural output. This point is also in accordance with the theoretical analysis. Equation (10) suggests that all variables have a positive promoted-effect on total agricultural output. More specifically, $1 \%$ increase in the agricultural capital input will result in $0.305 \%$ in the total agricultural output. $1 \%$ increase in the agricultural labor input will result in $0.397 \%$ in the total agricultural output. $1 \%$ increase in the agricultural product export will result in $0.510 \%$ in the total agricultural output. Compared with the cointegration test, the result demonstrates that the agricultural product impact \& export has a long-run positive promoted-effect on total agricultural output.

\section{Conclusion:-}

This paper pays much attention to the impact of agricultural product import \& export on total agricultural output in China. The annual data-sets from 1990 to 2016 is applied to analyze the impact of agricultural product import \& export on total agricultural output under the production function of export extension. Via the empirical analysis, the findings indicate that the agricultural product import \& export has a long-run positive promoted-effect on agricultural output. More specifically, $1 \%$ increase in the agricultural product export will result in $0.532 \%$ in the total agricultural output. $1 \%$ increase in the agricultural product import will result in $0.470 \%$ in the total agricultural output. $1 \%$ increase in the agricultural product export will result in $0.510 \%$ in the total agricultural output.

In summary, the agricultural product import \& export makes great contribution to the total agricultural output. This suggests that China's government should open its agricultural market more to the world so as to promote the growth 
of total agricultural output. As for agricultural product import and export, the empirical analysis results illustrate that the contribution of agricultural product export on total agricultural output is greater than that of agricultural product import. It means that China is till a big agricultural product export country. So, China's government should take measures to encourage the agricultural product export. Moreover, in order to keep the growth of total agricultural output, China's also should focus on the proper ratio of the agricultural capital input and the agricultural labor input.

\section{References:-}

1. De Silva, N., Malaga, J., \& Johnson, J. (2013, February). Trade liberalization effects on agricultural production growth: the case of Sri Lanka. In Southern Agricultural Economics Association Annual (SAEA) Meeting, Orlando, Florida (pp. 2-5).

2. Edeme, R. K., Ifelunini, I. A., \& Nkalu, N. C. (2016). A Comparative Analysis of the Impact of Agricultural Exports on Economic Growth of ECOWAS Countries. Acta Oeconomica Pragensia, 2016(5), 31-46.

3. Godoy, D. C., \& Dewbre, J. (2016). Economic Importance of Agriculture for Sustainable Development and Poverty Reduction: The Case Study of Vietnam.

4. Greyling, J. C. (2012). The role of the agricultural sector in the South African economy (Doctoral dissertation, Stellenbosch: Stellenbosch University).

5. Klobuchar, A. (2013). The Economic Contribution of America's Farmers and the Importance of Agricultural Exports.

6. Lin, Y., Deng, X., \& Jin, Q. (2013). Economic effects of drought on agriculture in North China. International Journal of Disaster Risk Science, 4(2), 59-67.

7. Olayiwola, W. K., \& Ola-David, O. A. (2013, October). Economic integration, trade facilitation and agricultural exports performance in ECOWAS member states. In Presentation at the Eighth African Economic Conference on' Regional Integration in Africa', Johannesburg, South Africa.

8. Syed Waseem Gilani (2015). The Impact of Agricultural Imports and Exports on Agricultural Productivity. Journal of Economics and Sustainable Development (pp.109-116)

9. Uremadu, S. O., \& Onyele, K. O. (2016). The impact of selected agricultural exports on the growth of the domestic economy. Academia Journal of Agricultural Research, 4(5), 281-291.

10. Yao, A., \& Wan, L. (2015). The Study of Measuring China's Agricultural Export Cost to the United States and Its Impact on Trade Growth. International Business Research, 8(2), 181.

11. 孙会敏, \& 张越杰. (2016). 中国农产品进出口与农业结构优化的关系研究一一基于 VAR 模型和协整检验 的实证分析. 农业技术经济, (12), 4-12.

12. 孙会敏, 胡东兴, \& 刘丽艳. (2016). 吉林省农产品进出口对农业经济增长的效应一一基于出口扩展型生产 函数的实证研究. 中国农业资源与区划, 37(1), 174-180.

13. 钟飞燕. (2017). 农产品国际贸易对我国经济增长的影响. 改革与战略, 33(4), 158-160. 